2. To: (Receiving Organization)

DISTRIBUTION

5. Proj./Prog./Dept/Div.:

HANDI 2000

8. Originator Remarks:

11. Receiver Remarks:

11A. Design Baseline Document? Yes No
KEY WORDS: H2K, BMS, HANDI 2000, PEOPLESOFT. GENERAJ LEDGER, PROJECT COSTING, BUSINESS SYSTEM IMPLEMENTATION, FINANCE, AS-IS/TO-BE
3. From: (Originating Organization)

SYSTEMS FLUOR DANIEL HANFORD

6. Design Authority/Design AgentCog. Engr.:

DAWN E. ADAMS
4. Related EDT No.:

N/A

7. Purchase Order No:

$\mathrm{N} / \mathrm{A}$

9. Equip./ComponentNo.:

$\mathrm{N} / \mathrm{A}$

10. System/Bidg./Facility:

$\mathrm{N} / \mathrm{A}$

12. Major Assm. Dwg. No.:

$N / A$

13. Permit/Permit Application No.:

$\mathrm{N} / \mathrm{A}$

14. Required Response Date:

N/A

\begin{tabular}{|c|c|c|c|c|c|c|c|c|c|c|c|c|c|c|}
\hline 15. & & & & & DATA TR & WNSMITTTE & & & & & (F) & (G) & (H) & (I) \\
\hline $\begin{array}{l}\text { (A) } \\
\text { lem } \\
\text { No. }\end{array}$ & & (B) Docum & nt/Drawing 1 & & $\begin{array}{l}\text { (C) Sheet } \\
\text { No. }\end{array}$ & $\begin{array}{l}\text { (D) Rev. } \\
\text { No. }\end{array}$ & (E) $\mathrm{Ti}$ & itle or De & escriptic & ion of Data Transmitted & $\begin{array}{l}\text { Approval } \\
\text { Desig- } \\
\text { nator }\end{array}$ & $\begin{array}{c}\text { Reason } \\
\text { for Trans- } \\
\text { mittal }\end{array}$ & $\begin{array}{l}\text { Origi- } \\
\text { nator } \\
\text { Dispo- } \\
\text { stion }\end{array}$ & $\begin{array}{l}\text { Receiv- } \\
\text { er } \\
\text { Dispo- } \\
\text { sition }\end{array}$ \\
\hline 1 & HNE- & 2640 & & & $\mathrm{~N} / \mathrm{A}$ & 0 & $A C C R$ & RUALS & FOR & HANDI 2000 & & & & \\
\hline & & & & & & & BUSI & INESS & MANZ & AGEMENT SYSTEM & $N / A$ & 2 & & \\
\hline 2 & HNF - & 2641 & & & $\mathrm{~N} / \mathrm{A}$ & 0 & ALLO & DCATIC & ONS & FOR HANDI 2000 & & & & \\
\hline & & , & & & & & BUSI & INESS & MANZ & AGEMENT SYSTEM & $N / A$ & 2 & & \\
\hline 3 & HNF- & 2642 & & & $\mathrm{~N} / \mathrm{A}$ & 0 & BUDG & GET FC & $\mathrm{OR} \mathrm{H}$ & ANDI 2000 & & . & & \\
\hline & & & & & & & BUS I & INESS & MAN & AGEMENT SYSTEM & $\mathrm{N} / \mathrm{A}$ & 2 & & \\
\hline & (SEE & SHEET & & & & & & & & & & & & \\
\hline 16. & & & & & & & & KEY & & & & & & \\
\hline Appro & val Des & ignator $(F)$ & & & ason for Tran & ismittal (G & & & & & isposition ( & (H) \& (I) & & \\
\hline & $\begin{array}{l}\text { S, Q, D } \\
\text { WHC. } \\
\text { Sec. } 1\end{array}$ & $\begin{array}{l}\text { ORN/A } \\
\text { CM-3-5. } \\
2.7)\end{array}$ & $\begin{array}{l}\text { 1. Approv } \\
\text { 2. Release } \\
\text { 3. Informa }\end{array}$ & $\begin{array}{l}\text { val } \\
\text { ation }\end{array}$ & $\begin{array}{l}\text { 4. Review } \\
\text { 5. Post-Re } \\
\text { 6. Dist. (Re }\end{array}$ & $\begin{array}{l}\text { view } \\
\text { ceeipt Ackn }\end{array}$ & now. $R e$ & equired) & & $\begin{array}{l}\text { 1. Approved } \\
\text { 2. Approved w/comme } \\
\text { 3. Disapproved w/com }\end{array}$ & ent & $\begin{array}{l}\text { 4. Review } \\
\text { 5. Review } \\
6 . \text { Receipt }\end{array}$ & $\begin{array}{l}\text { red no/con } \\
\text { red w/com } \\
\text { tacknowl }\end{array}$ & $\begin{array}{l}\text { mment } \\
\text { nment } \\
\text { ledged }\end{array}$ \\
\hline 17. & & & & & & $\begin{array}{l}\text { SIG } \\
\text { e Approval }\end{array}$ & $\begin{array}{l}\text { NATUR } \\
\text { IDEsigr }\end{array}$ & $\begin{array}{l}\text { REJDIST/ } \\
\text { nator for }\end{array}$ & $\begin{array}{l}\text { RIBUT } \\
\text { Rlequir }\end{array}$ & ION & & & & \\
\hline $\begin{array}{l}\text { (G) } \\
\text { Rea- } \\
\text { son }\end{array}$ & $\begin{array}{l}\text { (H) } \\
\text { Disp. }\end{array}$ & (J) Name & $\overbrace{}^{\prime \prime}$ & (K) Signa & re $\quad$ (L) $D$ & ate $(M)$ & MSIN & \begin{tabular}{c|} 
(G) \\
Rea- \\
son
\end{tabular} & $\begin{array}{l}(\mathrm{H}) \\
\text { Disp. }\end{array}$ & (J) Name & (K) Signat & : (L & -) Date & (M) MSIN \\
\hline 2 & 1 & Design $A L$ & thority (U) & aus & dans & $8 . 1 9 \longdiv { 9 8 }$ & & & & Central & File & $\Rightarrow B$ & $1-04$ & \\
\hline & & Design $A C$ & & & & & & & & & & & & \\
\hline & & Cog. Eng. & & & & & & & & & & & & \\
\hline & & Cog. Mgr. & & & & & & & & & & & & \\
\hline & & QA & & & & & & & & & & & & \\
\hline & & Safety & & & . & & & & & & & & & \\
\hline & & Env. & & & & & & & & & & & - & \\
\hline A4) & $\begin{array}{l}\text { ised! } \\
\text { ature of } \\
\text { nator }\end{array}$ & EDThes & $\frac{8-10-58}{\text { Date }}$ & $\begin{array}{l}19 . \\
\text { N/A } \\
\text { Authon } \\
\text { for Red }\end{array}$ & $\begin{array}{l}\text { Represen } \\
\text { iving Organiz }\end{array}$ & $\begin{array}{l}\text { tative } \\
\text { cation }\end{array}$ & $\overline{\text { Date }}$ & $\frac{\text { Doyid }}{\text { Design }}$ & $\begin{array}{l}\text { nafino } \\
\text { zant } M\end{array}$ & 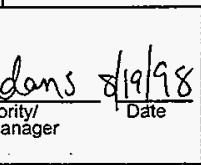 & $\begin{array}{r}\text { 21. DOE } \\
\text { Ctrif } \\
\square \\
\square \\
\square\end{array}$ & $\begin{array}{l}\text { APPROV } \\
\text { No. } \\
\text { Approved } \\
\text { Approved } \\
\text { Disapprove }\end{array}$ & w/comme & ents \\
\hline
\end{tabular}




\section{ENGINEERING DATA TRANSMITTAL}

(CONTINUATION PAGE)

5. Proj.Prog/Dept.Div.:

HANDI 2000
6. Cog. Eng.

DAWN E. ADAMS
1. EDT

625358

Page 2 of 4

15.

(A)

Item

(B) DocumentDrawing No.

No.

$4 \quad$ HNF -2746

\begin{tabular}{|l|l}
\hline 5 & ENF -2643 \\
\hline
\end{tabular}

\begin{tabular}{|l|l}
\hline & \\
\hline 6 & $H N F-2644$ \\
\hline
\end{tabular}

\begin{tabular}{|}
\hline \\
\hline
\end{tabular}

$7 \quad$ HNF -2645

HENF -2646

HNF-2649

$10 \quad$ HNF -2648

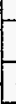

\begin{tabular}{|l|l}
\hline & \\
\hline & \\
\hline 12 & HNF -2650 \\
\hline
\end{tabular}

\begin{tabular}{|l|l}
\hline 13 & HNF-2651 \\
\hline
\end{tabular}

\section{DATA TRANSMITTED}

\begin{tabular}{|c|c|c|c|c|c|c|}
\hline $\begin{array}{c}\text { (C) } \\
\text { Nheet } \\
\text { No. }\end{array}$ & $\begin{array}{c}\text { (D) } \\
\text { Rev. } \\
\text { No. }\end{array}$ & $\begin{array}{c}\text { (E).Title or Description of Data } \\
\text { Transmitted }\end{array}$ \\
\hline
\end{tabular}

\begin{tabular}{|c|c|c|c|}
\hline$(F)$ & $(G)$ & $(H)$ & $(I)$ \\
\hline $\begin{array}{c}\text { Approval } \\
\text { Desig- } \\
\text { nator }\end{array}$ & $\begin{array}{c}\text { Reason } \\
\text { for } \\
\text { Trans- } \\
\text { mittal }\end{array}$ & $\begin{array}{c}\text { Origi- } \\
\text { nator } \\
\text { Dispo- } \\
\text { stion }\end{array}$ & $\begin{array}{c}\text { Receiv- } \\
\text { er } \\
\text { Dispo- } \\
\text { sition }\end{array}$ \\
\hline & & & \\
\hline
\end{tabular}

FIT GAP ANALYSIS FOR

HANDI 2000 BUSINESS

MANAGEMENT SYSTEM

CLOSING PROCEDURE FOR

HANDI 2000 BUSINESS

MANAGEMENT SYSTEM

FIXED ASSETS ACCOUNTING

FOR HANDI 2000 BUSINESS

MANAGEMENT SYSTEM

FUNDS CONTROL FOR HANDI

2000 BUSTNESS MANAGEMENT

SYSTEM

GL CHART OF ACCOUNTS

MAINTENANCE FOR HANDI

2000 BUSINESS MANAGEMENT

SYSTEM

.

HNF -2647

$\mathrm{N} / \mathrm{A}$

0

HANFORD BUSINESS

STRUCTURE FOR BUSINESS

MANAGEMENT SYSTEM

INVENTORY PROCESSES

FOR HANDI 2000 BUSINESS

MANAGEMENT SYSTEM

\begin{tabular}{ll|l|l} 
INVOICE/DISCAS FOR HANDI & N/A & 2
\end{tabular}

2000 BUSINESS MANAGEMENT

SYSTEM

LABOR COSTING FOR HANDI

2000 BUSINESS MANAGEMENT

SYSTEM

PASSPORT-PEOPLESOFT

INTEGRATION FOR HANDI

2000 BUSINESS MANAGEMENT

SYSTEM 


\section{ENGINEERING DATA TRANSMITTAL}

(CONTINUATION PAGE)

5. Proj.lProg./Dept.Div.:

HANDI 2000
6. Cog. Eng.

DAWN E. ADAMS
1. EDT

625358

(F)

15.

\begin{tabular}{|c|c|c|c|c|c|c|c|c|}
\hline $\begin{array}{l}\text { (A) } \\
\text { Item } \\
\text { No. }\end{array}$ & (B) Document/Drawing No. & $\begin{array}{l}\text { (C) } \\
\text { Sheet } \\
\text { No. }\end{array}$ & $\begin{array}{l}\text { (D) } \\
\text { Rev. } \\
\text { No. }\end{array}$ & $\begin{array}{l}\text { (E) Title or Description of Data } \\
\text { Transmitted }\end{array}$ & $\begin{array}{l}\text { Approval } \\
\text { Desig- } \\
\text { nator }\end{array}$ & $\begin{array}{l}\text { Reason } \\
\text { for } \\
\text { Trans- } \\
\text { mittal }\end{array}$ & $\begin{array}{c}\text { Origi- } \\
\text { nator } \\
\text { Dispo- } \\
\text { stion }\end{array}$ & $\begin{array}{l}\text { Receiv- } \\
\text { er } \\
\text { Dispo- } \\
\text { sition }\end{array}$ \\
\hline \multirow[t]{3}{*}{14} & HNF - 2652 & $\mathrm{~N} / \mathrm{A}$ & 0 & UNIT BILLED SERVICES FOR & $\mathrm{N} / \mathrm{A}$ & 2 & & \\
\hline & & & & HANDI 2000 BUSINESS & & & & \\
\hline & & & & MANAGEMENT SYSTEM & & & & \\
\hline \multirow[t]{3}{*}{15} & HNF -2653 & $\mathrm{~N} / \mathrm{A}$ & 0 & OTS CASH DISBURSEMENT & $\mathrm{N} / \mathrm{A}$ & 2 & & \\
\hline & & & & PROCESS FOR BUSINESS & & & & \\
\hline & & & & MANAGEMENT SYSTEM & & & & \\
\hline \multirow[t]{4}{*}{16} & HNF -2654 & $\mathrm{~N} / \mathrm{A}$ & 0 & TRAVEL EXPENSE & $\mathrm{N} / \mathrm{A}$ & 2 & & \\
\hline & $\therefore$ & & & REIMBURSEMENT FOR HANDI & & & & \\
\hline & & & & 2000 BUSINESS MANAGEMENT & & & & \\
\hline & & & & SYSTEM & & & & \\
\hline \multirow[t]{3}{*}{17} & HNF -2655 & $\mathrm{~N} / \mathrm{A}$ & 0 & CASH RECEIPTS RROCESS FOR & $\mathrm{N} / \mathrm{A}$ & 2 & & \\
\hline & & & & HANDI 2000 BUSINESS & & & & \\
\hline & & & & MANAGEMENT SYSTEM & & & & \\
\hline \multirow[t]{2}{*}{18} & HNF -2656 & $\mathrm{~N} / \mathrm{A}$ & 0 & INSURANCE PAYMENT PROCESS & $\mathrm{N} / \mathrm{A}$ & 2 & & \\
\hline & & & & FOR HANDI 2000 BUSINESS & & & & \\
\hline , & & . & & MANAGEMENT SYSTEM & & & & \\
\hline \multirow[t]{4}{*}{19} & HNF-2658 & $\mathrm{N} / \mathrm{A}$ & 0 & SAVINGS PLAN RAYMENT & & & & \\
\hline & & & & PROCESS FOR HANDI 2000 & & & & \\
\hline & & & & BUSINESS MANAGEMENT & & & & \\
\hline & & & & SYSTEM & & & & \\
\hline \multirow[t]{5}{*}{20} & HNF -2659 & $\mathrm{~N} / \mathrm{A}$ & 0 & WORK PERFORMED BY ENTER- & $\mathrm{N} / \mathrm{A}$ & 2 & & \\
\hline & & & & PRISE COMPANIES (ENCO) & & & & \\
\hline & & & & FOR (PHMC) FOR HANDI 2000 & & & & \\
\hline & & & & BUSINESS MANAGEMENT & & & & \\
\hline & & & & SYSTEMS & & & & \\
\hline \multirow[t]{4}{*}{21} & HNF - 2661 & $\mathrm{~N} / \mathrm{A}$ & 0 & WORK PERFORMED BY PHMC & $\mathrm{N} / \mathrm{A}$ & 2 & & \\
\hline & & & & FOR OHC-WORK ORDER FOR & & & & \\
\hline & . & & & HANDI 2000 BUSINESS & & & & \\
\hline & & & & MANAGEMENT SYSTEM & & & & \\
\hline \multirow[t]{4}{*}{22} & HNF -2662 & $\mathrm{~N} / \mathrm{A}$ & 0 & WORK PERFORMED BY OHC FOR & $\mathrm{N} / \mathrm{A}$ & 2 & & \\
\hline & & & & PHMC-WORK ORDER PROCESS & & & & \\
\hline & & & & FOR HANDI 2000 BUSINESS & & & & \\
\hline & (CONTINUED ON PG 4) & & & MANAGEMENT SYSTEM & & & & \\
\hline
\end{tabular}




\begin{tabular}{|c|c|c|c|c|c|c|c|c|}
\hline & $\cdots$ & ENGINE & $\begin{array}{r}\text { ERIN } \\
\text { (CON }\end{array}$ & $\begin{array}{l}\text { DATA TRANSMITTAL } \\
\text { INUATION PAGE) }\end{array}$ & & & & \\
\hline $\begin{array}{l}\text { 5. Proj. } \\
\text { HAN }\end{array}$ & $\begin{array}{l}\text { Prog.lDept.Div.: } \\
\text { DI } 2000\end{array}$ & 6. $\begin{array}{r}\text { Cos } \\
\mathrm{DA}\end{array}$ & $\begin{array}{l}\text { Eng. } \\
\text { N E. }\end{array}$ & DAMS & $\begin{array}{l}\text { 1. EDT } \\
625358\end{array}$ & & ge 40 & \\
\hline 15. & & DATA TR & NSMITT & & (F) & (G) & $(\mathrm{H})$ & (l) \\
\hline $\begin{array}{l}\text { (A) } \\
\text { Item } \\
\text { No. }\end{array}$ & (B) Document/Drawing No. & $\begin{array}{l}\text { (C) } \\
\text { Sheet } \\
\text { No. }\end{array}$ & $\begin{array}{l}\text { (D) } \\
\text { Rev. } \\
\text { No. }\end{array}$ & $\begin{array}{l}\text { (E) Title or Description of Data } \\
\text { Transmitted }\end{array}$ & $\begin{array}{l}\text { Approval } \\
\text { Desig- } \\
\text { nator }\end{array}$ & $\begin{array}{l}\text { Reason } \\
\text { for } \\
\text { Trans- } \\
\text { mittal }\end{array}$ & $\begin{array}{c}\text { Origi- } \\
\text { nator } \\
\text { Dispo- } \\
\text { stion }\end{array}$ & $\begin{array}{l}\text { Receiv- } \\
\text { er } \\
\text { Dispo- } \\
\text { sition }\end{array}$ \\
\hline 23 & YNF -2663 & $\mathrm{~N} / \mathrm{A}$ & 0 & WALK-IN WORK FOR OTHER & $N / A$ & 2 & & \\
\hline & & & & HANFORD CONTRACTORS FOR & & & & \\
\hline & . & & & HANDI 2000 BUSINESS & & & & \\
\hline & & & & MANAGEMENT SYSTEM & & & & \\
\hline 24 & HNF -2664 & $\mathrm{~N} / \mathrm{A}$ & 0 & DOE HANFORD REQUEST FOR & & & & \\
\hline & & & & SERVICES FOR HANDI 2000 & & & & \\
\hline & & & & BUSINESS MANAGEMENT & & & & \\
\hline & & & & SYSTEM & & & & \\
\hline & & & & & & & & \\
\hline & & & & & & & $\cdot$ & \\
\hline & & & & & & & & \\
\hline & & & . & . & & & & \\
\hline & & & $\cdot$ & & & & & \\
\hline & & & & & & & & \\
\hline & & & & & & & & \\
\hline & & & & & & & & \\
\hline & & & & & & & & \\
\hline & & & & & & & & \\
\hline & & & & & & & & \\
\hline & & & & & & & & \\
\hline & & & & & & & & \\
\hline & & & & & & & & \\
\hline & & & & & & & & \\
\hline & & & & & & & & \\
\hline & & & & & & & & \\
\hline & & & & & & & & \\
\hline & & & & & & & & \\
\hline & . & & & & & & & \\
\hline & & & & & & & & \\
\hline & & & & & & . & & \\
\hline & & & & & & & & \\
\hline & & & & & & & & \\
\hline & & & & & & & & \\
\hline
\end{tabular}




\title{
INVOICE/DISCAS FOR HANDI 2000 BUSINESS MANAGEMENT SYSTEM
}

\author{
Diane Wilson, Fluor Daniel Hanford Co. \\ MSN 31-22, 2355 Stevens \\ Richland, WA 99352 \\ U.S. Department of Energy Contract DE-AC06-96RL13200

$\begin{array}{lll}\text { EDT/ECN: } 625358 & \text { UC: } 900 \\ \text { Org Code: } & \text { FK2 } 60000 & \text { Charge Code: } \\ \text { B\&R Code: } & \text { EW7070100 } & \text { Total Pages: } \\ & \text { YHPE }\end{array}$

Key Words: DOE-RL, COST INCURRED, FMD.

Abstract: Invoice: Fluor Daniel Hanford provides a hard copy invoice to DOE-RL summarizing the cost incurred, all cost accruals, and cost accrual reversals, and transfexs. An "invoice file" is also submitted to RI which is backup to the hard copy. The file format is consistent with guidance provided by RL Financial Management Division. Cost, accrual and reversal amount will be reported by the codes identified in the Distribution of Obligations Report issued by the Contracting officer...

TRADEMARK DISCLAIMER. Reference herein to any specific commercial product, process, or service by trade name, trademark, manufacturer, or otherwise, does not necessarily constitute or imply its endorsement, recommendation, or favoring by the United States Government or any agency thereof or its contractors or subcontractors.

Printed in the United States of America. To obtain copies of this document, contact: Document Control Services, P.O. Box 950, Mailstop H6-08, Richland WA 99352, Phone (509) 372-2420; Fax (509) 376-4989.

PeopleSoft is a trademark of Indus corp.

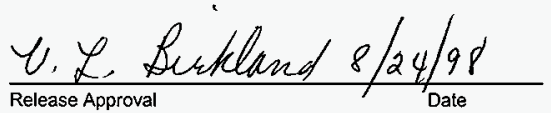

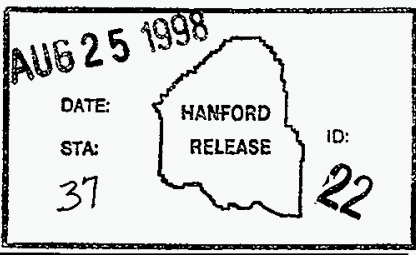

Release Stamp 


\section{Memorandum}

To:
D.E. Adams G1-21.
M.J. Byrd
$\mathrm{H} 2-08$,
A.A. Carter H2-19,
C.R. Hopkins G1-57,

K.B. Adamsons H2-19

R.C. Corless H2-19,

J.A. Caldwell G1-22,

R.J. McFadzean H2-19

From: P. C. Felts

Date: April 17, 1998

Re: PeopleSoft General Ledger / Project Costing -- Business System Implementation Sessions Final Documentation

\section{HANDI 2000 - Finance}

Attached for your information is the complete set of documentation of the work flow analysis from the Business System Implementation (BSI) Sessions.

One of the goals of finalizing documentation from the BSI Sessions is to use the documents as a communication tool.

Other goals of the BSI sessions were to validate the As-Is process, and describe the vision of the To-Be process that fit the baseline software processes. In the future, this documentation will be accessible electronically via a read-only shared area.

I thank you and your staff for your support during this information gathering and envisioning stage of the new system implementation project

If you have any questions, I can be reached on 376-0367 or via email.

Attachment 
Date:

$4 / 17 / 98$

Documentation: Finance Business System Implementation (BSI) Sessions

\section{Processes Included:}

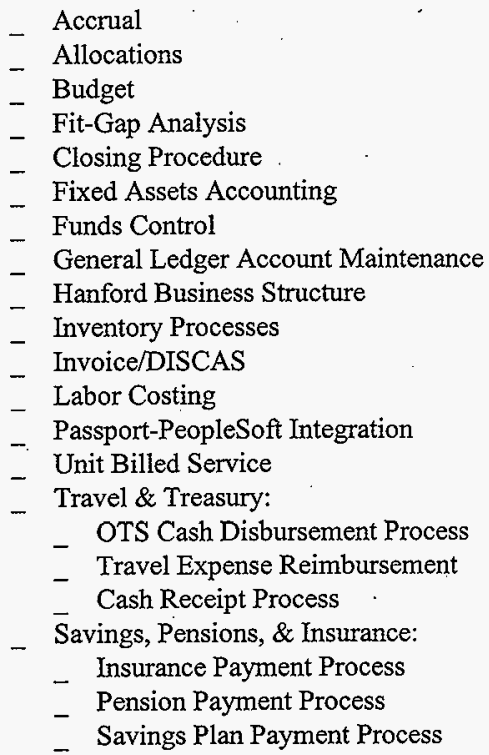

- Other Hanford Contractors:

- _ Worked Performed by Enco's for PHMC

- Worked Performed by Enco's for OHC

- Worked Performed by PHMC for OHC - Work Order

- Worked Performed by OHC for PHMC - Work Order Process

- Worked Performed by PHMC for OHC - Walk In

- Worked Performed by PHMC for DOE-Richland using the Request for Service Process

FDH Project Lead: Name

Signature

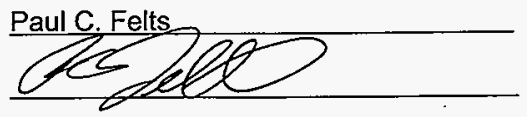




\section{Invoice/DISCAS}

\section{Overview}

- Invoice: Fluor Daniel Hanford provides a hard copy invoice to DOE-RL summarizing the cost incurred (checks written against the letter of credit), all cost accruals, and all cost accrual reversals, and transfers. An "invoice file" is also submitted to RL which is backup to the hard copy. The file format is consistent with guidance provided by RL Financial Management Division (FMD). Cost, accrual, and reversal amount will be reported by the codes identified in the Distribution of Obligations Report issued by the Contracting Officer and the associated WBS/TPCN codes that are used to identify specific tasks. Cumulative costs, accruals, and reversals reported should not exceed the cumulative amount authorized for each code in the Distribution of Obligations Report.

Invoice: Since the M\&I contract with Fluor Daniel Hanford includes a letter of credit, the "invoice" is not a mechanism which is submitted for cost reimbursement but a memorandum depicting how dollars from the letter of credit were spent for the month. RL utilizes the invoice file to distribute data to the RL Contracting Officer Representatives to "approve" the expenditures of US Treasury dollars.

DISCAS - FDH is responsible for preparing summarized cost, accruals, and accrual reversals for the month from the Invoice detail file to feed the Department of Energy accounting system due by close of business, the third working day of the following calendar month in the format specified by RL FMD.

DISCAS - the process of submitting a summarized file is in effect for edit purposes only. Once edit issues have been addressed by general ledger adjustments, they are recorded to the invoice file.

\section{Assumptions}

MISSION CRITICAL - must still meet the basic RL reporting requirements with the new system implementation.

- PeopleSoft General Ledger and Projects Module does not provide for the DOE Data elements which must be maintained. Rather than customizing the Peoplesoft products, an external crosswalk table will be developed to maintain the DOE Data Elements necessary for reporting.

NOTE: The DOE Invoice/DISCAS process has been deferred. It was determined to be more of a reporting/interface process and therefore needed to fall later in the project schedule. It has been rescheduled for May $11-26,1998$. In addition, completion of other BSI Sessions was necessary before beginning to address this process.

\section{Policies}

\section{As-Is Procedures}

To-Be Procedures

Impacts

Issues \& Action Items 
